\title{
Three stripes sign: muscle involvement with internal fibrosis in a patient with sarcoidosis
}

\author{
Naoki Tsujimoto, ${ }^{1}$ Takeshi Saraya, ${ }^{2}$ Masafumi Shimoda, ${ }^{1}$ Hajime Goto ${ }^{2}$
}

${ }^{1}$ Kyorin University School of Medicine, Mitaka, Japan

${ }^{2}$ Department of Respiratory Medicine, Kyorin University, Mitaka, Japan

\section{Correspondence to} Dr Takeshi Saraya, sara@yd5.so-net.ne.jp

Accepted 25 May 2014

\footnotetext{
To cite: Tsujimoto $\mathrm{N}$, Saraya T, Shimoda M', et al. BMJ Case Rep Published online: [please include Day Month Year] doi:10.1136/ bcr-2014-204691
}

\section{DESCRIPTION}

A 62-year-old previously healthy woman was referred to the orthopaedic department because of bilateral thigh pain accompanied by palpable subcutaneous nodules in both thighs. The extremity coronal MRI with fat-suppressed T2-weighted images showed an inner stripe of decreased signal intensity with outer stripes of increased signal intensity, the so-called three stripes sign, both in the left vastus lateralis (figure $1 \mathrm{~A}$, arrow) and bilateral vastus medialis muscles (figure $1 \mathrm{~A}$, arrowheads), while, on axial image, decreased signal intensity, a 'dark star' sign was seen both in the left vastus lateralis (figure $1 \mathrm{~B}$, arrow) and bilateral vastus medialis muscles (figure $1 \mathrm{~B}$, arrowheads). Furthermore, on H\&E staining, the biopsied specimens obtained from the left vastus lateralis demonstrated non-caseating epithelioid cell granulomas (figure 1C) or epithelioid cells (figure 1D). Thus, she was diagnosed with muscular sarcoidosis. The frequency of involvement of the mediastinal lymph nodes, lungs and muscle is $85 \%, 20 \%$ and 20 $75 \%$, respectively. However, the frequency of symptomatic muscle involvement, such as pain, nodular swelling and muscle weakness, is less than $0.5 \%$. In this regard, the present case had the former two findings as an atypical initial presentation. Muscular sarcoidosis is a rare condition which is clinically divided into nodular and myopathic types. The three stripes sign is a specific sign for nodular type of muscular sarcoidosis ${ }^{1}$ and is characterised by (1) a star-shaped central structure of decreased signal intensity, a 'dark star' sign on axial images which correspond to a dense fibrotic tissue and (2) inner stripe of decreased signal intensity (fibrotic tissue) and outer stripes of increased signal intensity (active inflammatory granuloma containing epithelioid cells) on coronal or sagittal images. ${ }^{23}$
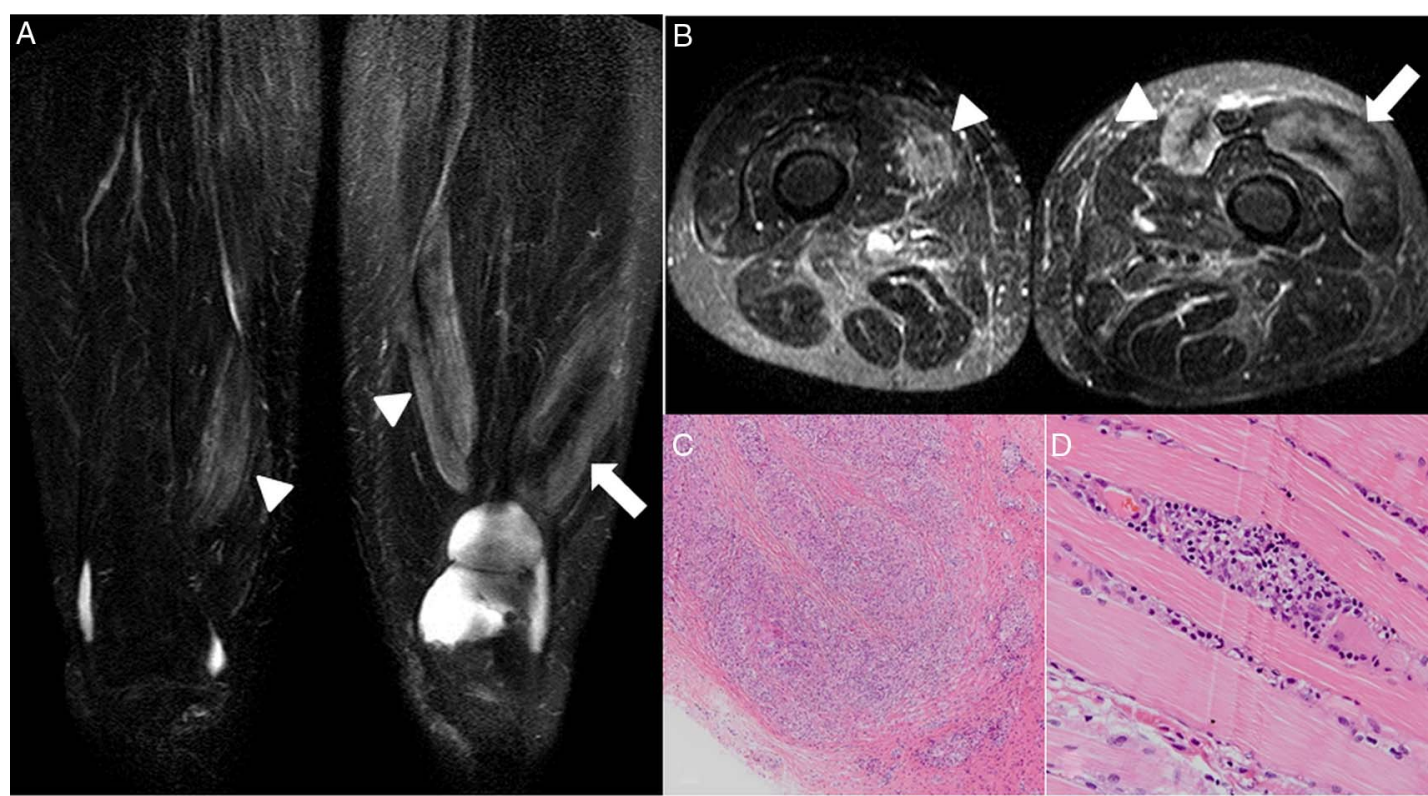

Figure 1 The extremity coronal MRI with fat-suppressed T2-weighted images showing an inner stripe of decreased signal intensity with outer stripes of increased signal intensity, the so-called three stripes sign, both in the left vastus lateralis $(A$, arrow) and bilateral vastus medialis muscles. ( $A$, arrowheads). The extremity axial MRI with fat-suppressed T2-weighted images showing decreased signal intensity, a 'dark star' sign both in the left vastus lateralis $(B$, arrow) and bilateral vastus medialis muscles. ( $B$, arrowheads). On H\&E staining, the biopsied specimens obtained from the left vastus lateralis demonstrated non-caseating epithelioid cell granulomas (C) or epithelioid cells (D). 


\section{Learning points}

- The frequency of symptomatic muscular sarcoidosis, such as pain, nodular swelling and muscle weakness, is less than $0.5 \%$.

- On MRI, the three stripes sign is a specific sign for nodular type of muscular sarcoidosis, which is characterised as inner stripe of decreased signal intensity and outer stripes of increased signal intensity on coronal or sagittal images, and dark star sign on axial images.

- The pathological findings for three stripes sign is that the centre area of a sarcoid nodule with decreased signal intensity is corresponded to a dense fibrotic tissue, and outer area of increased signal intensity is made up of an active inflammatory granuloma containing epithelioid cells.
Contributors NT, TS, MS and HG managed the patient in outpatient and inpatient settings.

Competing interests None.

Patient consent Obtained.

Provenance and peer review Not commissioned; externally peer reviewed.

\section{REFERENCES}

1 Otake $\mathrm{S}$, Imagumbai $\mathrm{N}$, Suzuki $\mathrm{M}$, et al. MR imaging of muscular sarcoidosis after steroid therapy. Eur Radiol 1998;8:1651-3.

2 Otake S, Banno T, Ohba S, et al. Muscular sarcoidosis: findings at MR imaging. Radiology 1990;176:145-8.

3 Otake S. Sarcoidosis involving skeletal muscle: imaging findings and relative value of imaging procedures. AJR Am J Roentgenol 1994;162:369-75.

Copyright 2014 BMJ Publishing Group. All rights reserved. For permission to reuse any of this content visit http://group.bmi.com/group/rights-licensing/permissions.

BMJ Case Report Fellows may re-use this article for personal use and teaching without any further permission.

Become a Fellow of BMJ Case Reports today and you can:

- Submit as many cases as you like

- Enjoy fast sympathetic peer review and rapid publication of accepted articles

- Access all the published articles

- Re-use any of the published material for personal use and teaching without further permission

For information on Institutional Fellowships contact consortiasales@bmjgroup.com

Visit casereports.bmj.com for more articles like this and to become a Fellow 